\title{
Once or Twice Response
}

National Cancer Institute

\section{Source}

National Cancer Institute. Once or Twice Response. NCI Thesaurus. Code C125226.

An indication that something occurs or occurred once or twice. 